九州大学学術情報リポジトリ

Kyushu University Institutional Repository

Descriptions of galatheids collected from coral reefs of the Ryukyu Islands (Crustacea, Anomura)

Miyake, Sadayoshi

Zoological Laboratory, Department of Agriculture, Kyushu University

Baba, Ke i j i

Zoological Laboratory, Department of Agriculture, Kyushu University

https://doi.org/10.5109/22748

出版情報：九州大学大学院農学研究院紀要. 14 (1)，pp.57-79，1966-06. Kyushu University バージョン：

権利関係 : 
Journal of the Faculty of Agriculture, Kyushu University, Vol. 14, No. 1 June, 30, 1966

Descriptions of galatheids collected from coral reefs of the Ryukyu Islands

(Crustacea, Anomura)*

Sadayoshi Miyake and Keiji BaBA

For the last four or five years we have collected a considerable number of galatheid specimens from the Ryukyu Islands. All of the specimens, distributed among seven species, exclusively belong to the genus Galathea and do not include deep-sea forms because the collectings were limited in the coral reefs.

Up to now only four species have been reported from the Ryukyu Islands (Stimpson, 1858; Ortmann, 1892; Miyake, 1953). In the present paper four were newly recorded and two others were described as new to science. The colorations were fully described. On the habitat, it is of interest to note that all the specimens were obtained among the branches of dead corals in tide-marks, where in almost all the cases hippolytid shrimps (chiefly Saron) were found to live with.

Before going further, we wish to express our gratitude to Prof. Kazuo Koba of Kumamoto University, who kindly took one of us to make scientific expeditions to Amami-oshima Island in 1964 and 1965, and afforded us facilities to this study. Our thanks are also due to $\mathrm{Mr}$. H. Minei of the Zoological Laboratory, Kyushu University for providing us with the materials upon which this paper is mainly based.

Galathea affinis Ortmann, 1892

(Figs: 1, 2)

Galathea affinis Ortmann, 1892, p. 252, pl. 11, fig. 9-Fiji Island (Type locality).

Galathea affinis: Borradaile, 1898, p. 463-Rotuma; Funafuti.

Galathea affinis: de Man, 1902, p. 711-Ternate.

* Contributions from the Zoological Laboratory, Faculty of Agriculture, Kyushu University, No. 342. 
Galathea affinis: Gordon, 1935, p. 4, figs. 1, 3-Banda Neira.

The carapace is nearly as long as broad excluding the rostrum. The gastric region is not distinctly circumscribed and two-spined in front.

The rostrum is slightly longer than broad, and armed on each lateral margin with fourt eeth. The external orbital angle is not spinulate. Behind the external orbital angle the carapace is armed with eight teeth. The pterygostomial flap has an acute tooth on the anterior margin near the pleural suture by which it articulates with the carapace. The anterior margin of the sternum of the third thoracic somite is round with a notch at the median.

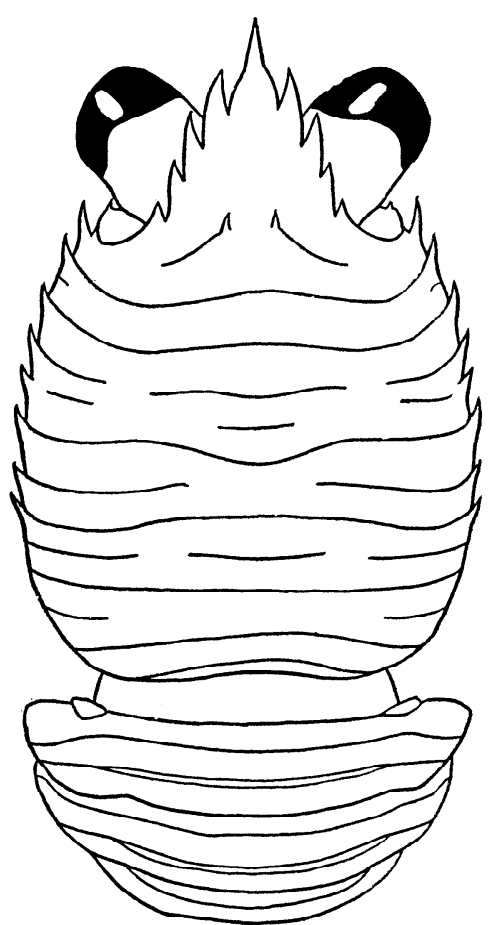

Fig. 1. Galathea affinis Ortmann, in dorsal view, $\times 14$, the fine setae omitted.

The merus of the third maxilliped is slightly longer than the ischium; the inner margin of the merus is armed with a strongly developed spine.

Chelipeds are ornamented with long setae on the upper and lower surface; the wrist, palm and movable finger are almost equal in length; the movable finger is furnished with four spines on the upper surface; there is a row of twelve acute spines on the outer margin of the palm and immovable finger; the upper surface of the palm is armed with three rows of spines; the wrist carries three spines on each of the inner and outer margins, its inner median one is the largest; two rows of spines are also placed on the upper surface of the wrist.

Colour. In live specimens the dorsal surface of the carapace is bluish and partly prussian blue. The upper surface of the abdominal segments is blue, and has yellowish brown blotches. The chelipeds and ambulatory legs are seashall pink being tinged with blue. A small rounded blue bird point exists near the distal end of the palm. The eye is bluish purple, the eye-stalk is olive.

Remarks. This species may be defined by the character that the anterior margin of the pterygostomial flap has a well developed spine near the pleural suture. 
The largest male measures $6.15 \mathrm{~mm}$, and the largest female $6.10 \mathrm{~mm}$, from the tip of the rostrum to the posterior margin of the carapace.

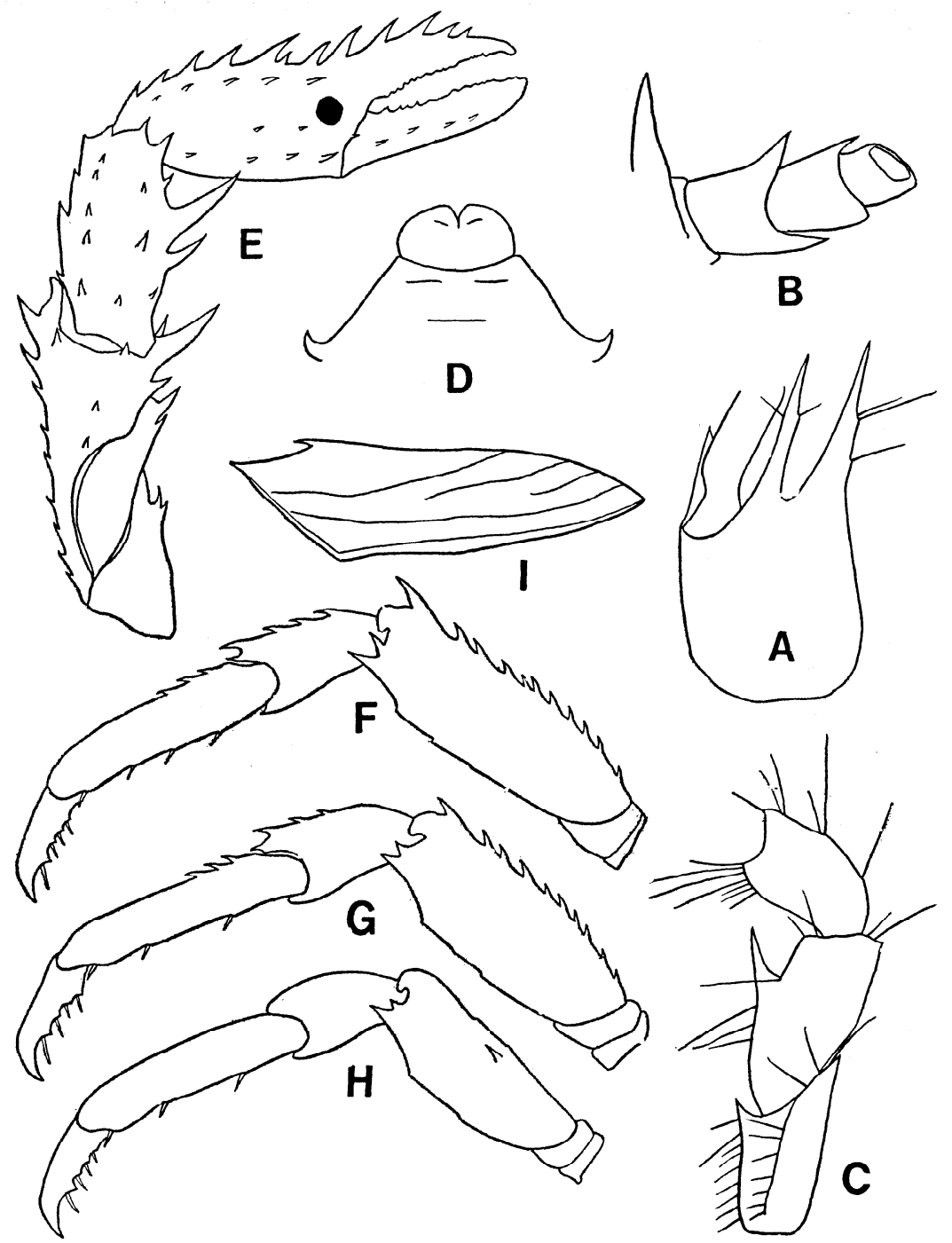

Fig. 2. Galathea affinis Ortmann

A. basal segment of left antennule, $\times 28$; B. left antennal peduncle, $` 28$; C. endopod of left third maxilliped, $\times 19$; D. anterior part ot sternal segments, $\times 19 ; \quad$ E. left cheliped, $\times 10 ; \quad$ F. left first ambulatory leg, $\times 19$; G. left second ambulatory leg, $\cdots 19$; H. left third ambulatory leg,

$\times 19$; I. left pterygostomial flap, $\times 8$. 


\section{Material examined.}

Komesu, southern coast of Okinawa-jima I., Ryukyu Is.; 14 令令, 2 ovig. 우우, Cat. No. 12428, Zoological Laboratory, Kyushu University (ZLKU); July 2, 1962 ; S. Miyake, T. A. Uchida and H. Minei leg.

Miyarawan, Ishigaki-jima I. ; 5 ㅎㅀ, 10 우우, Cat. No. 12444, ZLKU; Feb. 26, 1959; H. Minei leg.

Miyarawan, Ishigaki-jima I. ; 5 ิํ, 14 ovig. 우, Cat. No. 12459, ZLKU; Mar. 1959; H. Minei leg.

Aradake, Kumé-jima I. ; 2 於, 2 ovig. 우우, Cat. No. 12478, ZLKU ; Mar. 13, 1960 ; H. Minei leg.

O-jima, Kumé-jima I. ; 2 ోోई,, Cat. No. 12482, ZLKU ; Mar. 15, 1960 ; H. Minei leg.

Kitahara, Kumé-jima I. ; 2 ô่, 1 ovig. ㅇ, 1 우, Cat. No. 12484, ZLKU ; Mar. 14, 1960; H. Minei leg.

Yona, northern coast of Okinawa-jima I. ; 2 令, Cat. No. 12488, ZLKU; Apr. 8, 1961; H. Minei leg.

Nagusuku, southern coast of Okinawa-jima I.; 3 ồ, 1 ㅇ, Cat. No. 12490, ZLKU ; Apr. 30, 1961; H. Minei leg.

Gushichan, southern coast of Okinawa-jima I,; 1 o, 2 ovig. 우, 1 , Cat. No. 12494, ZLKU ; July 3, 1962 ; S. Miyake, T. A. Uchida and H. Minei leg.

Kasari, northern Pacific coast of Amami-oshima I.; 3 ồ, 4 ovig. 우우, 2 ㅇ, Cat. No. 12866, ZLKU ; July 29, 1965; K. Baba leg.

Shirokozaki, Amami-oshima I.; 1 ovig. , Cat. No. 12875, ZLKU; Aug. 3, 1965; K. Baba. leg.

\section{Galathea australiensis Stimpson, 1858}

(Figs. 3-5)

Galathea australiensis Stimpson, 1858, p. 251-Port Jackson [=Sydney] (Type locality). Galathea aegyptiaca Paul'son, 1875, p. 94 , pl. 12 , figs. $1-1 \mathrm{~b}[1961$, p. 100 , pl. 12, figs. $1-1 b]$-Red Sea.

Galathea australiensis: Haswell, 1882, p. 161-Port Jackson; Port Stephens.

Galathea australiensis: Henderson, 1888, p. 118, pl. 12, fig. 5-Arafura Sea.

Galathea australiensis: Pocock, 1890, p. 72-Macclesfield Bank.

Galathea australiensis: Ortmann, 1892, p. 251, pl. 11, fig. 8-Amami-oshima.

Galathea australiensis: de Man, 1902, p. 710-Ternate.

Galathea aegyptiaca: Nobili, 1906, p. 126, fig. 8, pl. 7, fig. 3-Red Sea.

Galathea australiensis: Stimpson, 1907, p. 230-No new record.

Galathea australiensis: Laurie, 1926, p. 123-Amirante; Saya de Malha, Cargados Carajos.

Galathea australiensis: Melin, 1939, p. 56, figs. 32-35-Bonin Islands.

Not Gatathea australiensis: Balss, 1913, p. 13, fig. 13. [=G. balssi Miyake et Baba, 1964] 
The carapace is as long as broad, the rostrum excluded. The sides of the carapace diverge posteriorly so that the greatest breadth is well behind the middle. The median part of the carapace is ornamented with long plumose setae. There are two spines in front of the gastric region. Four spinules are placed on the second transverse ridge behind the one on which the gastric spines stand. The external orbital angle is well developed and pyramid-like. The lateral margin of the carapace is armed with six teeth on each side, the fourth of which is the largest.

The rostrum is as long as broad, and armed with three acute teeth and a small one at the base. The dorsal surface is ornamented with a few long plumose setae.

The merus of the third maxilliped is slightly longer than the ischium, and its inner margin is bispinose.

The chelipeds are thickly furnished with plumose setae; the movable finger is three-fifths the length of the palm, being furnished with a row of spines on the upper surface; the outer margin of the immovable finger and palm is acutely spined; the palm is also spined along the inner margin, and bears two longitudinal rows of spines on the upper

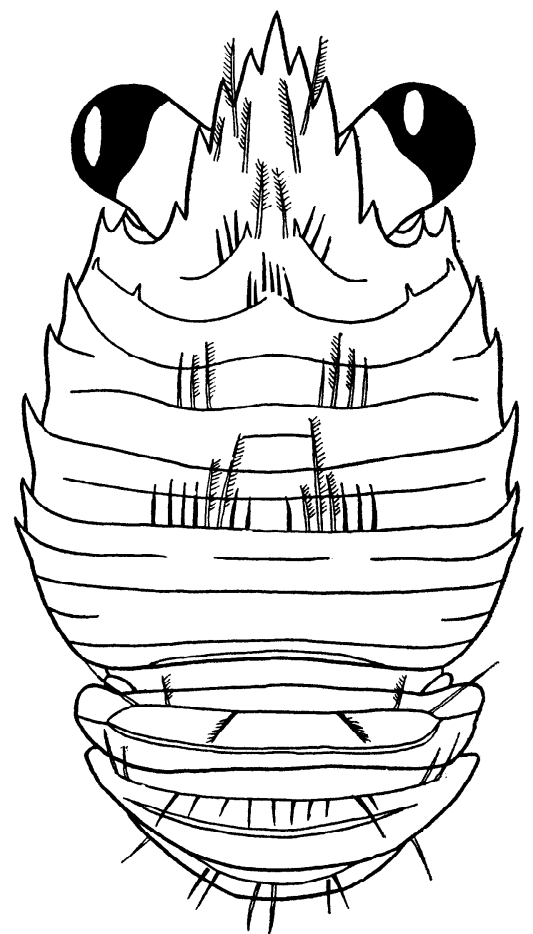

Fig. 3. Galathea australiensis Stimpson, in dorsal view, $\times 16$, the fine setae omitted.

surface; the wrist is four-fifths the length of the palm; it is armed with spines on both inner and outer margins, and also with two rows of spines on the upper surface.

The ambulatory legs are furnished with plumose setae. The outer margin of the merus of the first ambulatory leg is spined (8-9 spines), and the inner margin terminates in a distal spine; the outer margin of the carpus is also spined (4-5 spines); the propodus is furnished with three spinules on the outer margin; the dactylus has five teeth on the inner margin and from the base of each tooth a broad seta springs. The second pair of ambulatory legs are very similar to the first. In the third ambulatory leg the armature of the outer margin of each joint is weak. 
Colour. In live specimens, various colour patterns are observed on the carapace and abdomen only, and are divided into following five

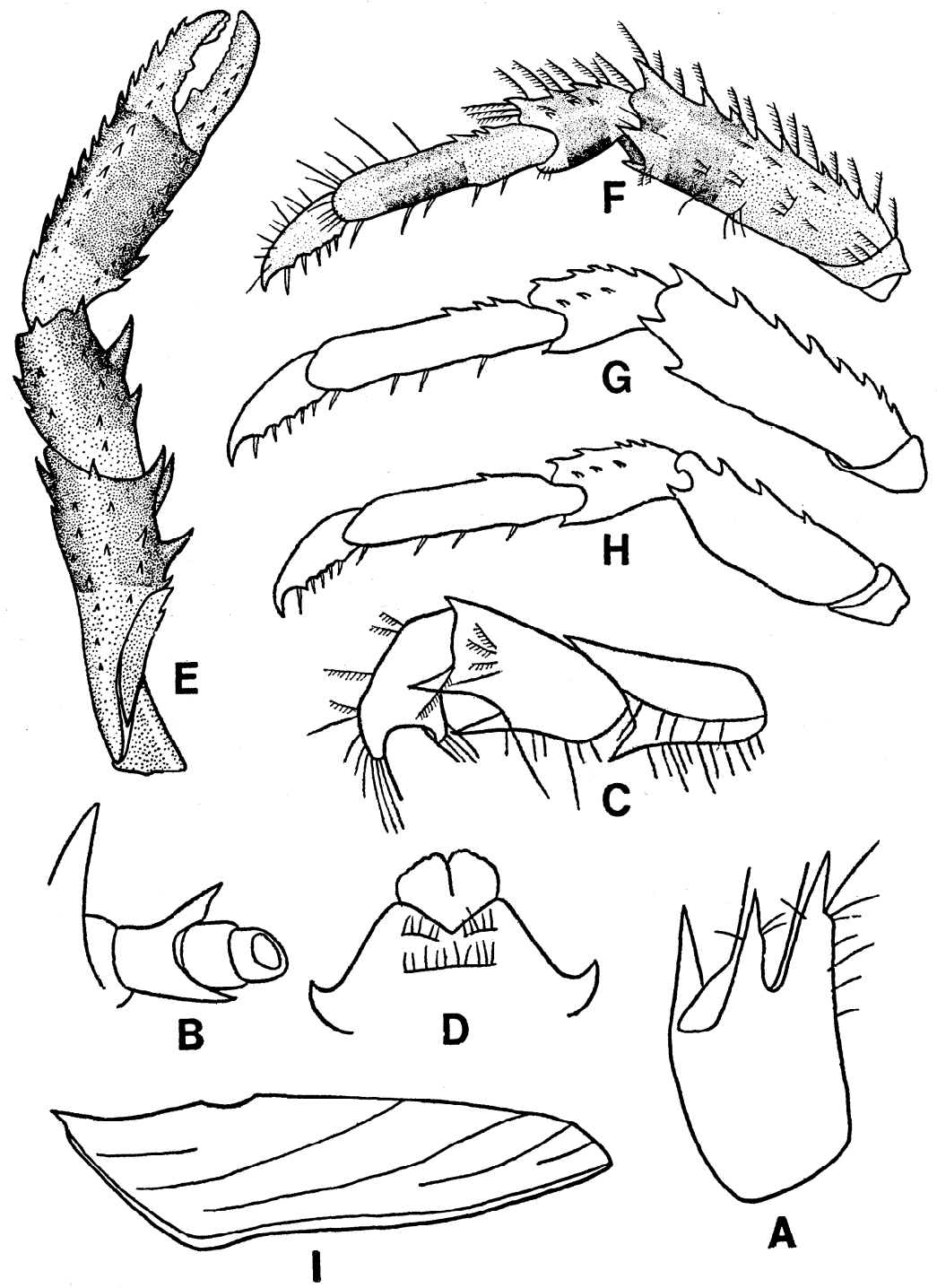

Fig. 4. Galathea australiensis Stimpson

A. basal segment of left antennule, $\times 28$; B. left antennal peduncle, $\times 28$; C. endopod of left third maxilliped, $\times 12$; D. anterior part of sternal segments, $\times 16$; E. left cheliped, $\times 16$; F. left first ambulatory leg, $\times 16$; G. left second ambulatory leg, $\times 16$; H. left third ambulatory leg, $\times 16$;

I. left pterygostomial flap, $\times 16$. 
groups which will be well understood with reference to Fig. 5.

1. Colour pattern A (CP. A).

The carapace has a broad white transverse strip on the middle, and also has a white speck on the middle of the dorsal surface of the second abdominal segment. All of the other portions are reddish. This pattern comprises five specimens ( $1 \hat{\delta}, 2$ ovig. 우우, 2 웅).

2. Colour pattern B (CP. B).

The following portions are reddish, i. e., the anterior one-third of the carapace including rostrum, both of the lateral portions of the posterior half of the carapace and the lateral portions of the fourth and fifth abdominal segments. All of the other portions are brownish. This comprises three specimens ( $2 \hat{o} \hat{\delta}, 1$ ovig. ㅇ).

3. Colour pattern $\mathrm{C}$ (CP. C).

This pattern is similar to the CP. B, but the abdomen is entirely brownish. This comprises three specimens (1 ovig. 우, 2 우우).

4. Colour pattern D (CP. D).

The anterior one-third of the carapace including rostrum is reddish, and other portions are wholly brownish. This comprises nine specimens (5 호수, 1 ovig. 우, 3 우우).

5. Colour pattern E (CP. E).

The carapace and abdomen are brownish on all over the surface. This comprises 58 specimens ( 32 소, 13 ovig. 우우, 13 우우).

The typical pattern is CP. E which occupies 74 per cent of all the specimens. As mentioned above, the coloration varies on the carapace and abdomen only, but on the other portions it is equal in all of the specimens presenting various colour patterns. The coloration of the chelipeds and ambulatory legs is, therefore, well understood by fully describing the specimens represented by the typical colour pattern $\mathrm{E}$.

That is as follows: The carapace is brownish. Setae on the carapace are red or white. Chelipeds have an olive band on each joint. The fingers are yellowish. The spines on the cheliped are red at the tip and blue at the base. The ambulatory legs have an olive band on each of the mcrus, carpus and propodus. Near the distal end the merus is speckled with spectum orange. Eyes are dusky purple.

Remarks. In the previous paper (Miyake and Baba, 1964) it was shown that the material recorded by Balss (1913) from Japan is not identical with G. australiensis. As a consequence it remains question. able whether Balss' material from the Red Sea (1915) is identical with 
this species. On the other hand, Melin (1939) treated G. aegyptiaca Paul'son as a synonym for $G$. australiensis. As a result of the comparison of our material with Paul'son's (1961) and Nobili's (1906) de-

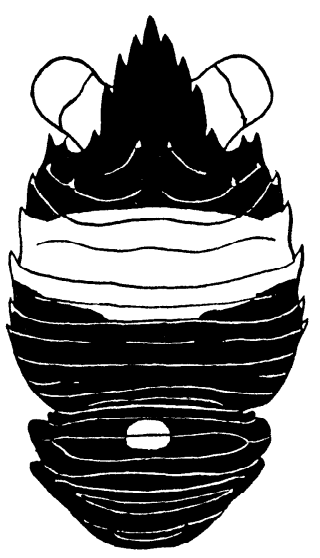

A

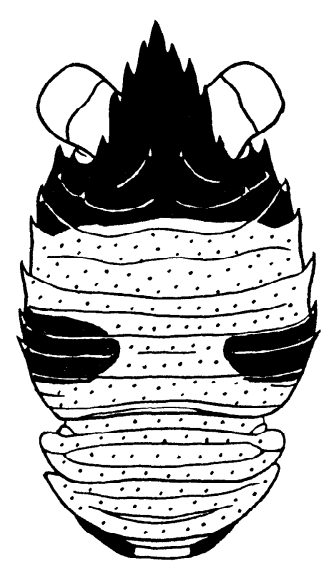

B

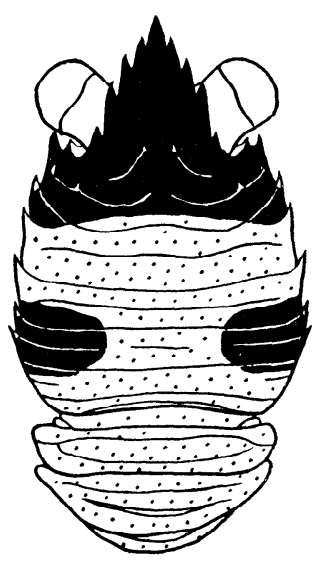

C

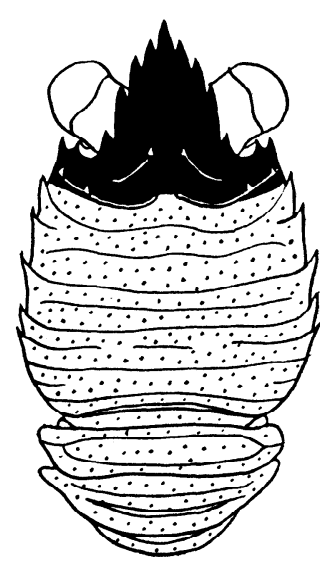

D

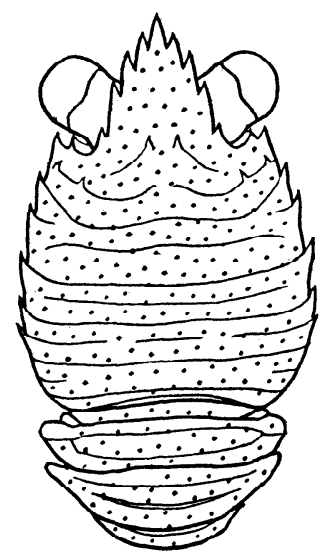

E

Fig. 5. Various colour patterns of Galalhea australiensis.

A. CP. A ; B. CP. B; C. CP. C; D. CP. D ; E. CP. E. white region, white; dotted region, brown; black region, red.

scriptions, Melin's proposal may be recognized with the exception of the number of the transverse ridges on the carapace.

The largest male measures $9.10 \mathrm{~mm}$, and the largest ovigerous female 
$8.15 \mathrm{~mm}$, from the tip of the rostrum to the posterior margin of the carapace.

\section{Material examined.}

Gushichan, southern coast of Okinawa-jima I.; 2 s。 (CP. E), 1 ovig. i (CP. B), Cat. No. 12498, ZLKU ; July 3, 1962 ; S. Miyake, T. A. Uchida and $\mathrm{H}$. Minei leg.

Miyarawan, Ishigai-jima I. ; 1 ô, Cat. No. 12505, ZLKU ; Feb. 26, 1959; H. Minei leg.

Kasari, northern Pacific coast of Amami-oshima I.; $27 \hat{\jmath} \hat{\jmath}, 9$ ovig. 우우, 12 우우 (CP. A, 5 ; CP. B, 1 ; C.P. C, 1 ; CP. D, 7 ; CP. E, 34) ; Cat. No. 12502, ZLKU; Aug. 5, 1964 ; K. Baba leg.

Kasari, northern Pacific coast of Amami-oshima I.; 12 $\hat{\jmath}, 8$ ovig. 우우, 8 우우 (CP. B, 1; CP. C, 2 ; CP. D, 2; CP. E, 23); Cat. No. 12881, ZLKU ; July 29, 31, Aug. 1, 1965; K. Baba leg.

\section{Galathea platycheles Miyake, 1953}

(Figs. 6, 7)

Galathea platycheles Miyake, 1953, p. 205, figs. 5, 6-Swo, Formosa (Type locality).

The carapace is broader than long excluding the rostrum. The striation is weak. There are one pair of plumose setae on the median line of the second transverse ridge. No spines on the gastric region. There is an acute pyramid-like tooth which forms the external angle of the orbit. Each lateral border of the carapace carries seven teeth. Behind the anterolateral spine which is the first lateral tooth, is a small supplementary tooth on each side. Just behind the insertion of the antenna there is a well developed spine which is not seen from a dorsal view.

The rostrum is nearly as long as broad, and armed with four teeth on each side. The upper surface of the rostrum is furnished with short fine setae.

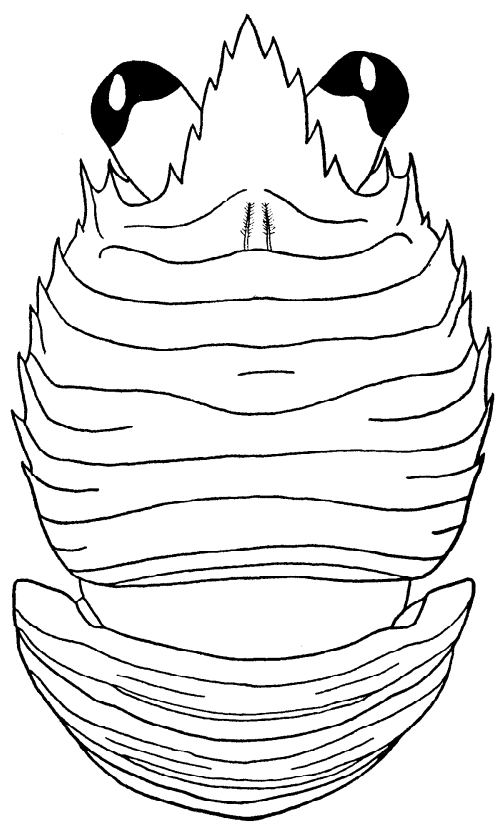

Fig. 6. Galathea platycheles Miyake, in dorsal view, $\times 15$, the fine setae omitted.

At the inner distal angle the ischium of the third maxilliped bears 
a small somewhat inwardly directed spines; the merus is slightly longer than the ischium and has a large spine on its inner margin; one of our specimens (Cat. No. 12525) has two spines on the same, the distal of which is rather small.

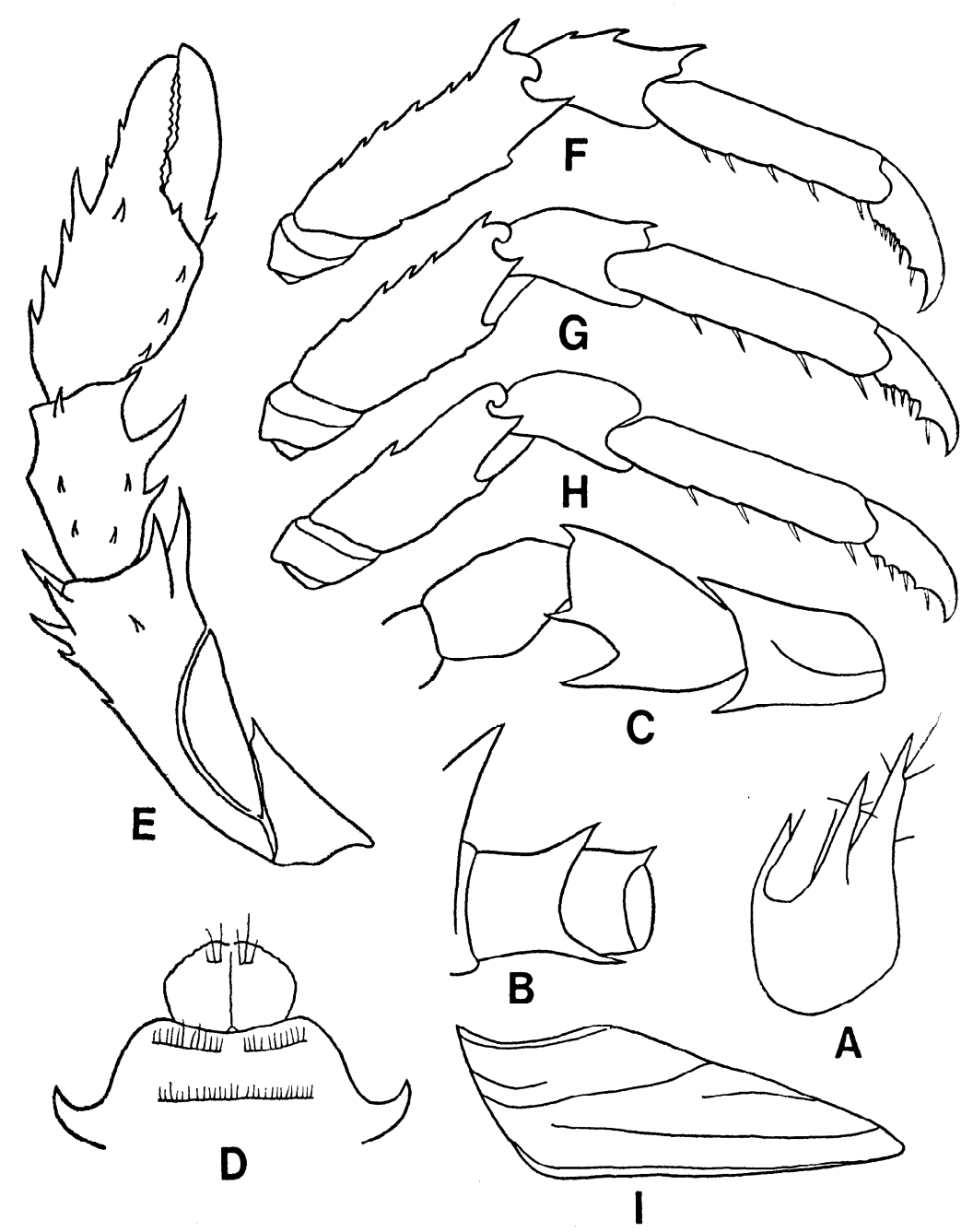

Fig. 7. Galathea platycheles Miyake

A. basal segment of left antennule, $\times 28$; $\quad$ B. left antennal peduncle, $\times 28$; C. endopod of left third maxilliped, $\prec 16$; D. anterior part of sternal segments, $\times 16$; E. left cheliped, $\times 16$; F. left first ambulatory leg, $\times 16 ; \quad$ G. left second ambulatory leg, $\times 16 ; \mathrm{H}$. left third ambulatory leg, $\times 16 ; \mathrm{I}$. left pterygostomial flap, $\times 16$. 
Chelipeds agree well with the original description. The meri of the first and second pairs of ambulatory legs are armed with small spines on the outer margin, one of which at its distal end is large. The third ambulatory leg has a rather large spine on the outer median margin of the merus. Two sharp spines are placed on the outer margin of the carpus of the first. Similarly, a small spine is on the outer distal margin of the second, and none on that of the third. The propodus of the first is armed with five sharp and elongated spines on the inner margin. Those of the second and third pairs have four spines.

Colour. In five per cent of formalin, the carapace is golden yellow and fringed on the transverse ridges with orange vermillion. The fifth and sixth lateral spines on the carapace are white. Each ambulatory leg has two light seashell pink bands on the propodus, and also has two yellowish brown bands on the dactylus.

In live specimens, this species is yellowish white on all over the surface, being emphasized with yellowish grey on the carapace.

Remarks. The materials agree well with the description of species given by Miyake, apart from the arrangement of the striae on the sternum of the fourth thoracic somite. The present is the first subsequent record.

The larger male measures $2.90 \mathrm{~mm}$, and the ovigerous female $4.00 \mathrm{~mm}$, from the tip of the rostrum to the posterior margin of the carapace.

\section{Material examined.}

Komesu, southern coast of Okinawa-jima I.; 1 ovig. ㅇ, Cat. No. 12525, ZLKU; July 2, 1962 ; S. Miyake, T. A. Uchida and H. Minei leg.

O-jima, Kumé-jima I.; 1 o, Cat. No. 12526, ZLKU; Aug. 31, 1959 ; H. Minei leg.

Shirokozaki, Amami-oshima I.; 1 s, Cat. No. 12911, ZLKU, Aug. 3, 1965, K. Baba leg.

\section{Galathea serrirostris Melin, 1939}

(Fig. 8)

Galathea scrirostris Melin, 1939, p. 72, figs. 43-47-Port Lloyd $\lceil=$ Futami $\rceil$ : Tokinoura $[?=$ Takinoura $]$; Hatsume $[?=$ Hatsune $]$; east coast of Chichi-jima, Bonin Islands.

Galathea serrirostris: Miyake and Baba, 1965, p. 590, figs. 5, 6-near Muko-jima, Bonin Islrnds.

The specimens examined here are quite the same to the specimens from the Bonin Islands (Miyake and Baba, 1965), only apart from having three spines on the lateral margin of the carapace behind the cervical 
groove. Both of the specimens from the Bonin Islands and Amamioshima Island before us differ from the original description in the fact that the rostrum is not serrated at the base of the lateral margin.

The specimen in our collection from the Bonin Islands lacks ambulatory legs, but fortunately in the present collection they are well preserved. We do description the legs as the supplementary note to the previous paper of ours.

The merus of the first ambulatory leg bears eight spines on the outer margin, its inner distal corner forms an acute spine; the carpus bears three spines on the outer margin; the propodus has on the outer proximal margin a single spine, its inner margin bears five conical slender spines; the inner margin of the dactylus has four serrated teeth, and from each of the serrated teeth a broad seta springs. The second ambulatory leg is very similar to the first, with the exception that the armature of the merus is very weak. In the third ambulatory leg, the merus has only one spine placed slightly outside of the outer margin; the carpus with a small spine on the outer distal margin.

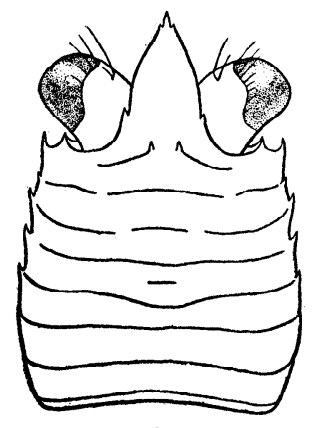

A

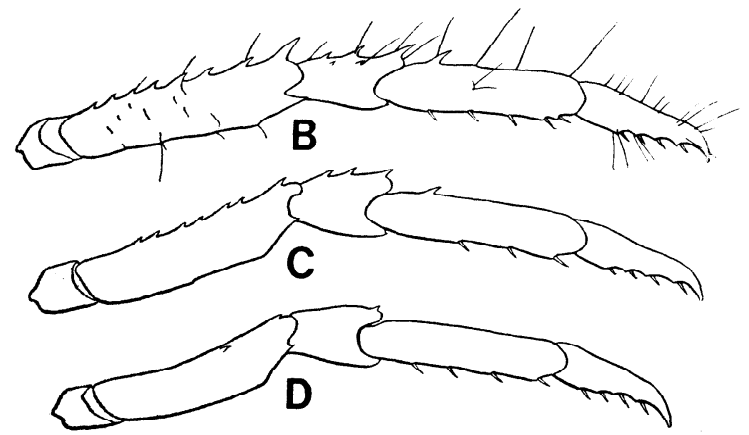

Fig. 8. Galathea serrirostris Melin

A. carapace in dorsal view, 16 , the fine setae omitted; B. right first ambulatory leg, 21 ; third ambulatory leg. $\times 21$.

C. right second ambulatory leg,

21 ; $\quad$. right

Colour. In five per cent of formalin this species is brownish yellow on all over the surface, being emphasized with orange vermillion on the transverse ridges of the carapace and abdomen.

The larger male measures $2.5 \mathrm{~mm}$ from the tip of the rostrum to the posterior margin of the carapace.

\section{Materials examined.}

Kasari, northern Pacific coast of Amami-oshima I.; $2 \hat{\jmath} \hat{\delta}$, Cat. No. 12912, KLKU ; July 30, 1965; K. Baba leg. 
Galathea bimaculata sp. nov.

(Figs. 9, 10)

Description of holotype. The carapace is slightly broader than long excluding the rostrum. The upper surface is rather smooth. The striation is weak and provided with the usual fringe of fine setae. Striae on the hepatic region are short, wavy and scale-like. There are short strong setae on the first transverse ridge and on the hepatic regions. No spines on the gastric region. The lateral margin of the carapace bears six teeth on the left, and five on the right of which the third is wanting. The external orbital angle is rounded and unarmed. Behind the insertion of the antenna lies a well developed and forwardly directed spine being not seen from a dorsal view.

The rostrum is as long as broad, and armed with three acute teeth of subequal size and the small one at the base on each side; the tip of the rostrum is sharp and elongated; the dorsal surface is slightly pubescent.

The basal segment of the antennular peduncle is armed with three spines on the distal margin, one of which extends nearly to the tip of the rostrum. The second segment of the antenna is armed with an outer and an inner distal marginal spine.

The merus of the third maxilliped is longer than the ischium, its inner

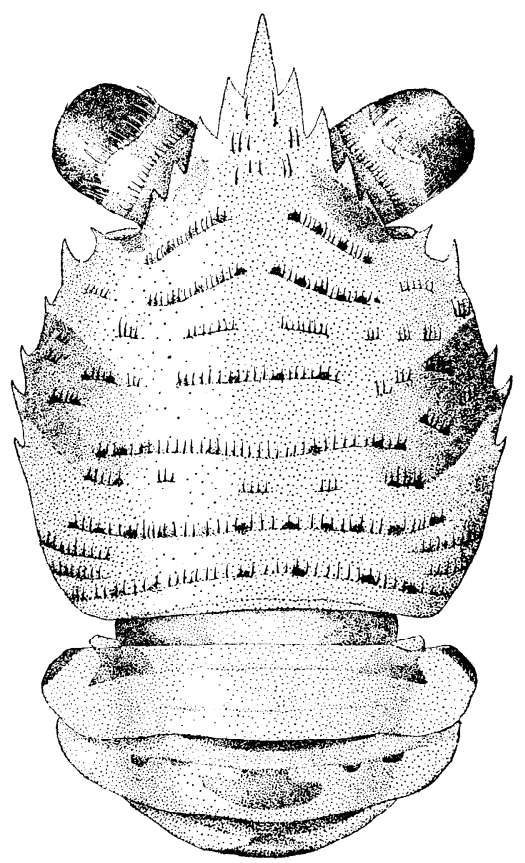

Fig. 9. Galathea bimaculata sp. nov., holotype, male, in dorsal view, 13. margin is bispinose; the outer meral and carpal margins are smooth.

The chelipeds are subequal and similar; they are furnished with long coarse setae which are particularly developed on the distal half of each joint; they are also armed with rather acute spines on the outer and inner margins and on the upper surface; the movable finger is equal to the wrist in length and slightly shorter than the palm; the cutting margin of each finger is provided with a prominent tubercular tooth.

Each pair of the ambulatory legs bears a row of spines along the outer margin of the merus, carpus and propodus; a second row of 
spines lies to the outer side of the marginal carpal row; there are also spines on the inner margin of the propodus and dactylus; the outer meral margin of each ambulatory leg is furnished with broad setae.
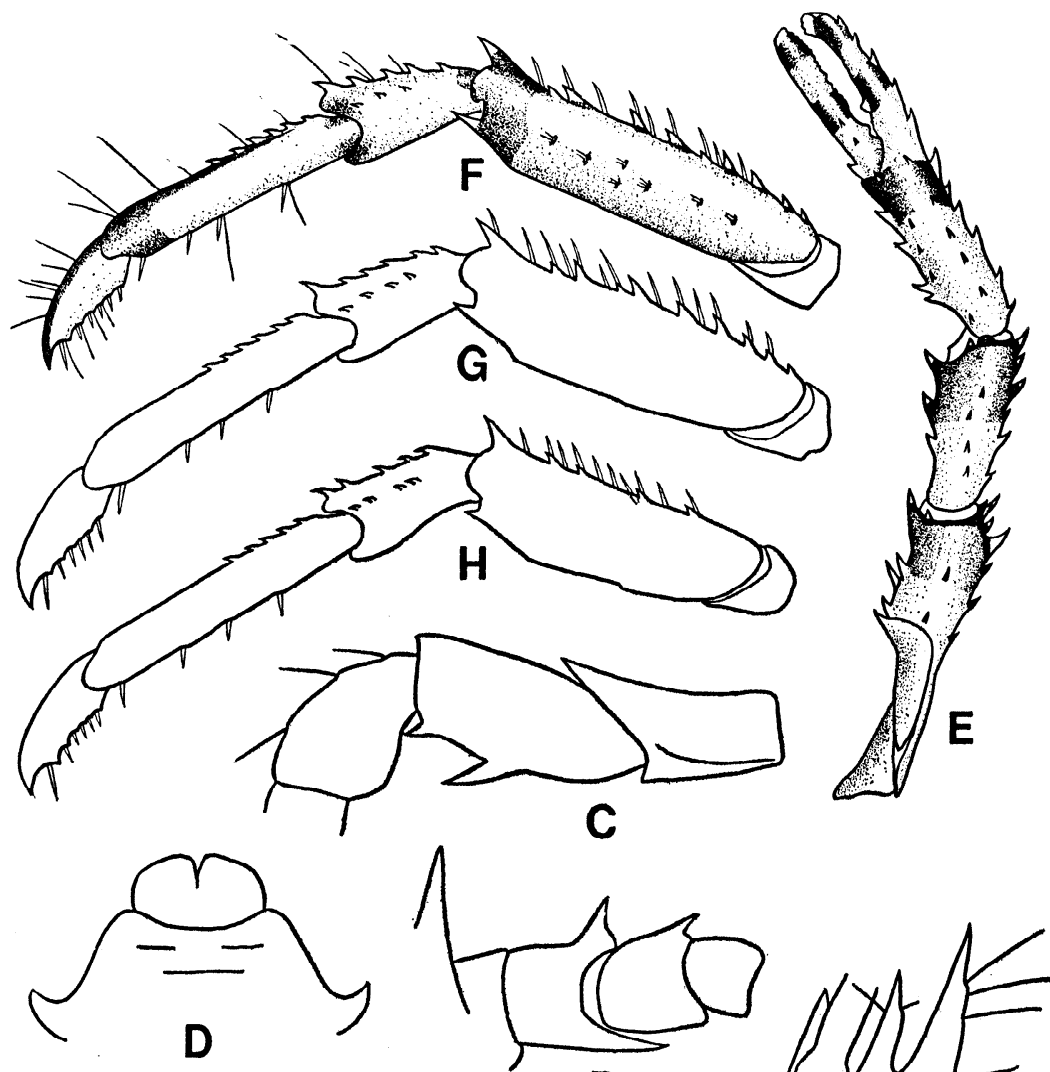

B
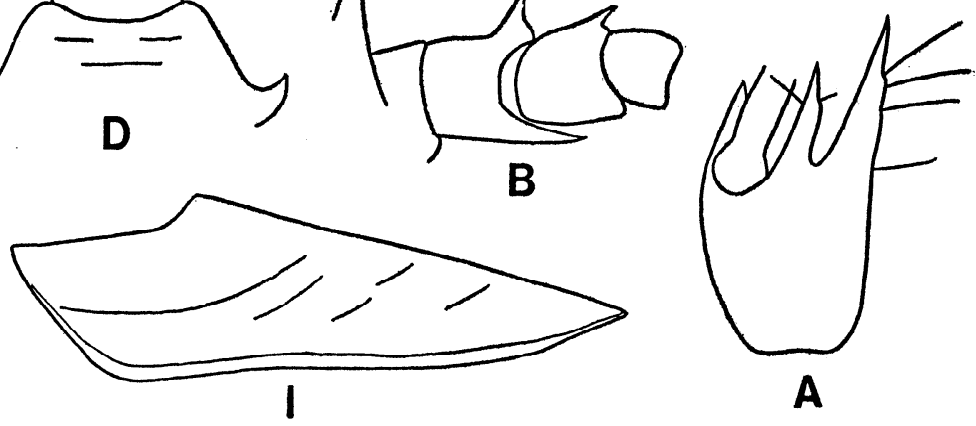

Fig. 10. Galathea bimaculata sp. nov., holotype.

A. basal segment of left antennule, $\times 29$; B. left antennal peduncle, $\times 29$; C. endopod of left third maxilliped, $\times 29$; D. anterior part of sternal segments, $\times 19$; E. right cheliped, $\times 8$; F. left first ambulatory leg, $\times 19 ; \mathrm{G}$. left second ambulatory leg, $\times 19$; H. left third ambulatory leg, $\times 19 ; \quad I$. left pterygostomial flap, $\times 19$. 
Colour. In live specimens the ground colour is light seashell pink. On the median parts each of the lateral margins of the carapace has blue or brown blotches which represent the name of this species. There are small speaks of holly berry colour on the transverse ridges. The first abdominal segment is blue, and the others have speckles of amber red colour. All the segments of the abdomen are tinged with blue. Fingers of the cheliped are marked with white and holly berry rings. The ambulatory legs are reddish on the distal portion of the merus, on the distal portion and outer margin of the propodus, and on the outer margin of the dactylus. The merus is scattered above with small reddish specks circulated with blue. Eyes are dusky purple. Eye-stalks are brownish yellow.

Measurements in holotype (in $\mathrm{mm}$ ):

Length of carapace including rostrum .................... 5.25

Breadth of carapace ...................................... 3.85

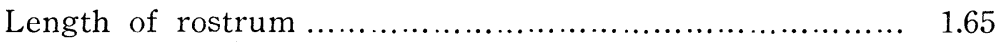

Breadth of rostrum.......................................... 1.65

Length of cheliped ......................................... 12.60

Length of wrist ............................................ 2.40

Breadth of wrist ............................................ 0.80

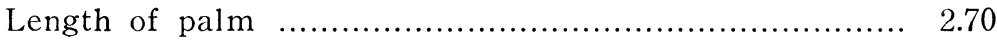

Breadth of palm ............................................. 0.70

Length of movable finger .................................. 2.40

Variations. Lateral marginal spines on the carapace are usually six in number including the one just behind the external orbital angle. However, of all the specimens two have seven spines, one of which adds to the last in position, and another two have five spines of which the second is wanting. Number of outer meral spines varies from eight to eleven in the first and second ambulatory legs, but the first tends to have fewer spines than the second. The outer carpal spines are usually five, but three specimens have six or seven spines. The outer margin of the propodus is armed with a row of six to eight spines. The third maxillipeds have constantly two spines on the inner meral margin, but its distal spine is small.

There are two colour patterns. The first pattern has brown blotches on both left and right sides of the carapace as in the holotype. The second pattern has blue blotches on the same. In all the specimens from Okinawa-jima Island (Cat. No. 12526), the first pattern is represented by males, and the second pattern females. However, in the specimens from Amami-oshima Island (Cat. No. 12540, Cat. No. 12876), the first pattern consists of 12 specimens of males and eight specimens of females, and the second pattern includes eight specimens of males 
and 13 females.

Remarks. This species is allied to G. formosa de Man in the general arrangement of the transverse ridges on the carapace but it is easily distinguished from the latter by the form of the rostrum, and by the coloration on the carapace.

The largest male measures $6.20 \mathrm{~mm}$, and the largest ovigerous female $5.80 \mathrm{~mm}$, from the tip of the rostrum to the posterior margin of the carapace.

Types. Holotype, $\hat{o}$, Cat. No. 12528, ZLKU; Gushichan, southern coast of Okinawa-jima I.; July 3, 1962; S. Miyake, T. A. Uchida and H. Minei leg. Paratyes: 1 ô, Cat. No. 12538, ZLKU; Aradake, Kumé-jima I.; Mar. 13, 1960; H. Minei leg. 1 ovig. 우 Cat. No. 12539, ZLKU ; O-jima,

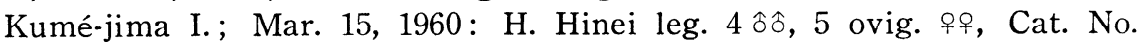
12529, ZLKU; Gushichan, southern coast of Okinawa-jima I.; July 3, 1962 ; S. Miyake, T. A. Uchida and H. Minei leg. 18 ôô, 13 ovig. 우우, 5 ㅇ, Cat. No. 12540, ZLKU; Kasari, northern Pacific coast of Amami-

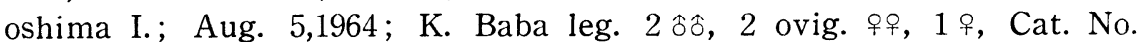
12876, ZLKU; Kasari, northern Pacific coast of Amami-oshima I.; July 30, 1965 ; K. Baba, leg.

Galathea pilosa de Man, 1888

(Fig. 11, 12)

Galathea pilosa de Man, 1888, p. 460, pl. 19, fig. 4-Amboina (Type locality).

Galathea pilosa ?: Edmondson, 1951, p. 196, fig. 7-Christmas Island.

The carapace is slightly broader than long. The upper surface is furnished with long coarse setae on the transverse ridges. The arrangement of the transverse ridges is as represented in Fig. 11. Two spines and two spinules on the gastric region. On the dorsal surface of the carapace, a spinc is present behind the orbit. There are one pair of spines on the anterior branchial region. One pair of spines are also placed on the middle transverse ridge.

The rostrum is as long as broad, and armed with four teeth on each side, its tip is not sharp; the first lateral tooth is small and its tip reaches to the level of the top of the second lateral tooth; the antcrior half of the upper surface is furnished with plumose setae, but the posterior half with smooth coarse setae.

The external orbital angle is rounded and unarmed. The anterolateral spine is well developed; on the left side a small spine follows it in front of the cervical groove, but none on the right side; behind it there are five spines of which the last is rather large.

The basal segment of the antennular peduncle is armed with four spines on the distal margin; the outermost of it is the largest, and the inner one small. The first segment of the antenna is armed with 
an inner and an outer distal marginal spine; the third segment with a spine on the inner distal margin.

The merus of the third maxilliped is one and a half times as long as the ischium; the merus is armed with three spines of equal size on the inner margin, its outer margin is smooth but the distal margin extends to form a small spine; the outer margin of the carpus is smooth. The sternum of the third thoracic somite is as represented in Fig. 12D; the anterior margin protrudes anteriorly and has a notch at the median. The pterygostomial flap has no spines on the upper surface.

The cheliped is furnished with plumose setae on the wrist, palm and fingers; the wrist is short and broader than long; the wrist is armed with three inner marginal and an outer distal marginal spine, and also with five spinules on the upper surface; the palm is as long as broad, and nearly as long as the movable finger; the outer margin of the palm and immovable finger is armed with five spines; the inner margin of the palm with four spines; the movable finger bears three spines on the outer margin.

The a mbulatory legs are ornamented

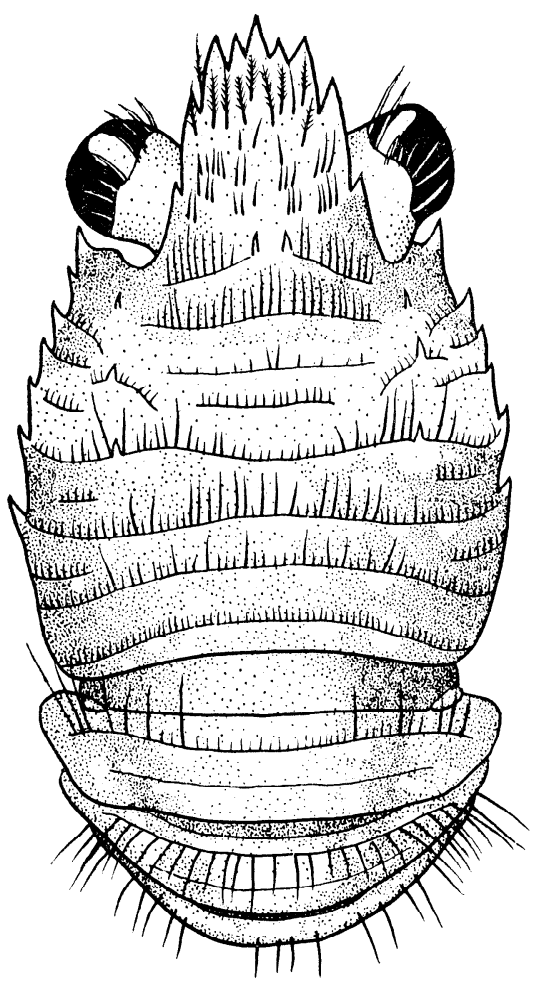

Fig. 11. Galathea pilosa de Man in dorsal view, 13 . with plumose setae on the merus and carpus. The merus of the first ambulatory leg carries ten spines on the outer margin, one of them at the distal is the strongest; the inner distal angle of the merus extends to form a strong spines; the carpus bears three spines on the outer margin, and a row of spines on the upper surface; the propodus has two spines on the proximal half of the outer margin, its inner margin is furnished with four long and slender spines; the inner margin of the dactylus is serrated, and from each of the serrated teeth a broad seta springs. The second ambulatory leg is very similar to the first. In the third ambulatory leg the armature is weak; there are no spines on the outer margin of the merus, but a row of three spines is placed on the upper surface; the inner distal angle of the merus is rounded. 
Colour. In five per cent of formalin the carapace and abdomen are reddish, and scattered with small white blotches. There is a white transverse stripe on the middle of the carapace. The rostrum is white. Strong setae on the transverse ridges of the carapace and abdomen are red or white. The arm of the cheliped has an amber

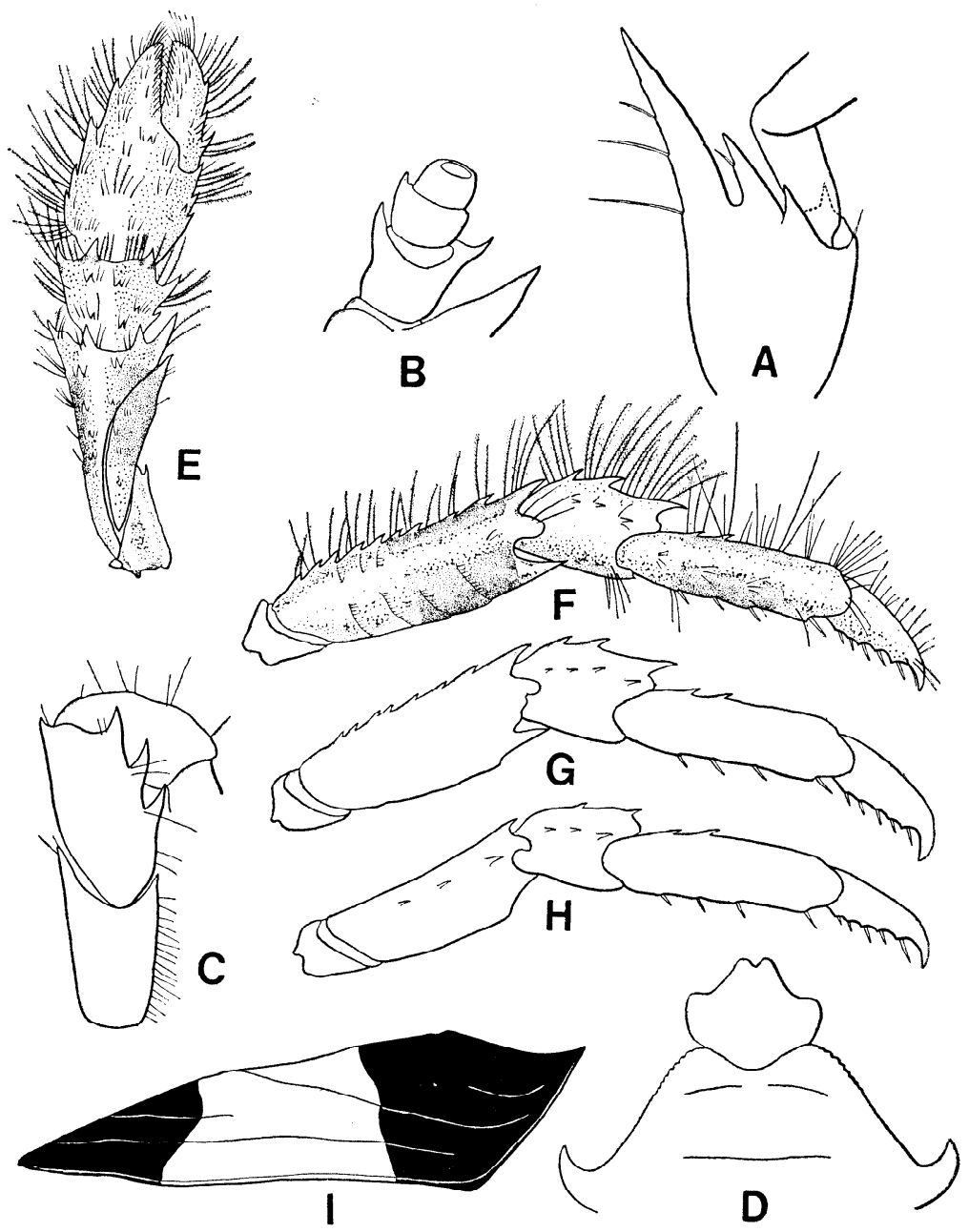

Fig. 12. Galathea pilosa de Man

A. basal segment of right antennule, $\times 21$; B. right antennal peduncle, $\times 28$; C. endopod of right third maxilliped, $\times 28 ;$ D. anterior part of sternal segments, $\times 28$; E. left cheliped, $\therefore 10 ; \quad$ F. right first ambulatory leg, $\times 14$; G. right second ambulatory leg, $\therefore 14$; H. right third ambulatory leg, $\therefore 14$; I. right pterygostomial flap, $\ltimes 19$. 
red band. The fingers are yellow. Each ambulatory leg has an are amber red band on the merus and on the propodus. The dactylus is yellow.

Remarks. The specimen agrees well with both of the de Man's and Edmondson's diagnoses, with the exception of the number of gastric spines and of the presence of the postcervical spines. This species is very allied to G. australiensis Stimpson in the armature of the carapace and in coloration, but it is easily distinguished by the following respects. (1) The merus of the third maxilliped is three-spined on the inner margin. (2) The basal segment of the antennular peduncle bears four spines on the distal margin. (3) The anterior margin of the sternum of the third thoracic somite protrudes anteriorly. This is also similar to G. formosa de Man in the shape of the rostrum, from which it differs in having gastric spines.

Measurements (in $\mathrm{mm}$ ):

Length of carapace including rostrum........................ 5.35

Breadth of carapace ............................................ 4.05

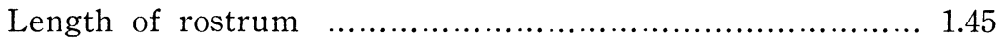

Breadth of rostrum ......................................... 1.40

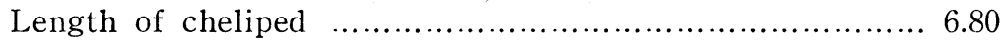

Length of wrist ............................................. 1.05

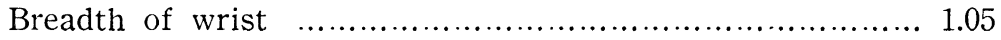

Length of palm ........................................... 1.70

Breadth of palm ........................................... 1.35

Length of movable finger .................................... 1.05

Material examined. Kasari, northern Pacific coast of Amami-oshima I. ; 1 s, Cat. No. 12576, ZLKU; Aug. 5, 1964 ; K. Baba leg.

\section{Galathea amamiensis sp. nov.}

(Fig. 13, 14)

Description of holotype. The rostrum is longer than broad, being provided with four teeth on its lateral margin; its dorsal surface is sparsely equipped with short setae. The external orbital angle is rounded and unarmed. The lateral margin of the carapace carries six spines, the first one immediately outside of the external orbital angle is strongly developed. There are two gastric spines on the first transverse stria. Two spines are also placed on the edges of the second transverse ridge (Fig. 13).

The basal segment of the antennule bears three spines on the distal margin, the outer one of them is the largest; a small spine is also present on the outer margin. The anterior prolongation of the first 
segment of the antenna is short; the second segment is armed with an outer distal marginal and an inner distal marginal spine; the third segment with a small distal spine on the inner margin.

In the third maxilliped the ischium is nearly as long as the merus, its inner toothed ridge has minute closely placed denticles; the merus is armed with two spines on the inner margin, its outer distal margin forms a small spine; the carpus is smooth.

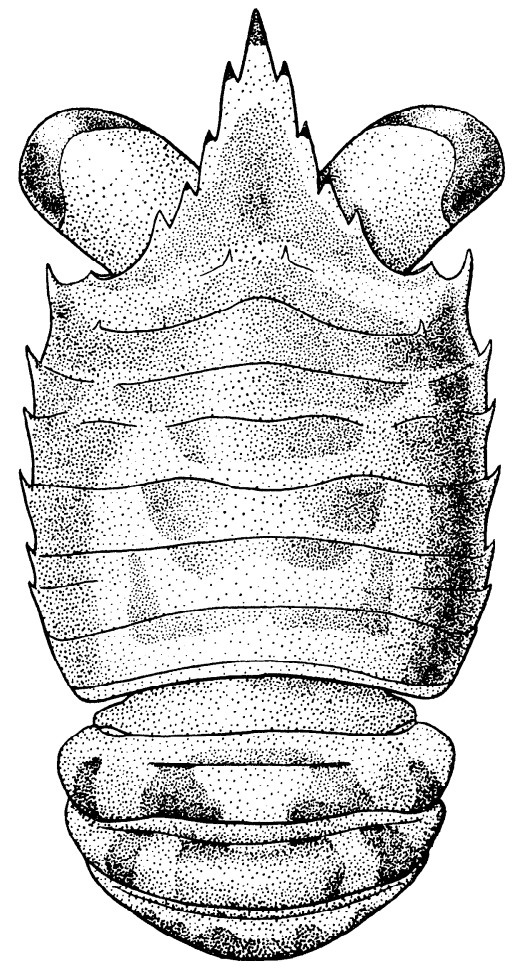

Fig. 13. Galathea amaniensis sp. nov., holotype, male, in dorsal view, 29.

Chelipeds are sparsely furnished with long setae; there are three rows of spines on the wrist, i.e., two on both margins and one on the upper surface; the palm is longer than the wrist, and bears three rows of spines, of which the two on both margins are acute and one on the surface weak; the movable finger is about two-thirds as long as palm; its inner margin is spined; the cutting margins are tuberculous.

The merus of the first ambulatory leg is armed with eight spines on the outer margin, the inner margin forms a spine at the distal corner, and is slightly spined immediately behind the distal one; three spines are lined up along the outer margin of the carpus; two spines lie to the outer side of the marginal carpal row; the propodus, sparsely having long setae, bears a minute spine on the proximal outer margin; four long slender spines are arranged along the inner margin of the propodus; the dactylus bears four serrated teeth, and from each of the serrated teeth a broad seta springs. The second ambulatory leg is quite similar to the first. In the third ambulatory leg, the armature is very weak; the carpus is smooth.

The sternum of the third thoracic somite protrudes anteriorly, having a notch at the anterior margin.

The pterygostomial flap has a minute spine at the anterior corner.

Colour. In five per cent of formalin, the carapace is, on all over the surface, bluish being tinged with light yellowish brown. But such 
portions as each tip of the rostral teeth and the second and fifth transverse ridges of the carapace are emphasized with orange vermillion. The abdomen is coloured in the same manner to the carapace. In the pterygostomial flap, two blue patches tinged with light yellowish brown are placed on the anterior and posterior portions. The proximal and distal portions of the arm and wrist are emphasized with blue tinged
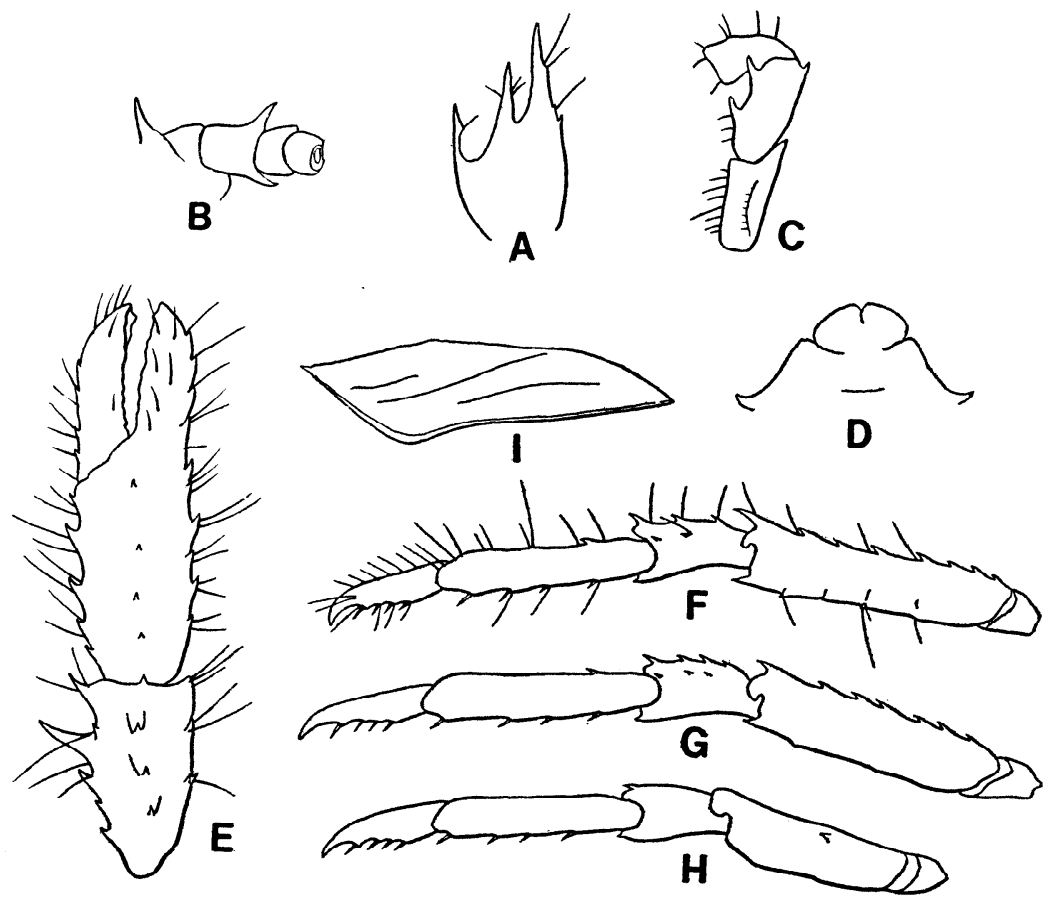

Fig. 14. Galathea amamiensis sp. nov., holotype.

A. basal segment of left antennule, 334 ; B. left antennal peduncle, $\times 34$; C. endopod of left third maxilliped, $\varkappa 22$; D. anterior part of sternal segments, $\times 32$; E. left cheliped, $\times 23$; F. left first ambulatory leg, $\times 24$; G. left second ambulatory leg, $\times 24 ; \mathrm{H}$. left third ambulatory leg, $\times 24 ; \mathrm{I}$. left pterygostomial flap, $\ltimes 25$.

with yellowish brown; the palm is tinged with blue and the middle portion is complicated with a brown colour. The fingers are fairly yellowish; spines on the palm are orange vermillion; the palm and fingers bear plumose setae which are divided into two colours, the basal red and the distal white; The setae as those are also scattered on the wrist. The colour of the ambulatory legs is very similar to that of the cheliped. 
Measurements in holotype (in $\mathrm{mm}$ ):

Length of carapace including rostrum........................ 2.60

Breadth of carapace.......................................... 1.70

Length of rostrum............................................. 0.90

Breadth of rostrum ........................................ 0.70

Length of cheliped ............................................ 4.60

Length of wrist ............................................. 0.90

Breadth of wrist ............................................. 0.50

Length of palm .............................................. 1.10

Breadth of palm ........................................... 0.50

Length of movable finger ................................... 0.80

Remarks. This species is very similar to G. australiensis Stimpson but it differs from the latter in the following respects. (1) The rostrum is rather long. (2) The anterior part of the carapace is devoid of plumose setae. (3) The external orbital angle is not pyramid-like. (4) The lateral margin of the carapace lacks a small spine in front of the cervical groove. This is also very allied to G. balssi Miyake et Baba in the appearance of the carapace, but it is distinguished by the armature of the third maxilliped, and by the shape of the sternum of the third thoracic somite.

Type. Holotype, ô, Cat. No. 12914, ZLKU; Kasari, northern Pacific coast of Amami-oshima I. ; July 30, 1965; K. Baba leg.

\section{References}

Balss, H. 1913. Ostasiatische Decapoden. I. Galatheiden und Paguriden. Abh. K. Bayer. Akad. Wiss., München, Math.-Phys. Kl., suppl.-vol. 2, Abth. 9, pp. 1-85, figs. 156 , pls. $1,2$.

Balss, H. 1915. Die Decapoden des Roten Meeres. II. Anomuren, Dromiaceen und Oxystomen. Denkschr. Kaiserl. Akad. Wiss., Math.-Naturw. Kl., Wien, vol. 92, pp. 1-20, figs. 1-9.

Borradaile, L. A. 1898. On some crustaceans from the South Pacific. Part II. Macrura anomala. Proc. Zool. Soc. London, 1898, pp. 457-468, pl. 36.

Edmondson, C. H. 1951. Some Central Pacific crustaceans. Occ. Pap. Bishop Mus. Honolulu, vol. 20, no. 13, pp. 183-243, figs. 1-38.

Gordon, I. 1935. Résultats scientifiques du voyage aux Indes Orientales Méerlandaises de LL. AA. RR. le Prince et la Princesse Leopold de Belguique. Anomura (excluding Paguridea). Mém. Mus. Roy. Hist. Nat. Belguique, Bruxelles, Hors série, vol. 3 , fasc. 17 , pp. 1-12, figs. $1-5$.

Haswell, W. A. 1882. Catalogue of the Australian stalk-eyed Crustacea. pp. i xxiv, 1-324, figs. $1-8$, pls. 1-4.

Henderson, J. R. 1885. Diagnoses of the new species of Galatheidea collected during the "Challenger" expedition. Ann. Mag. Nat. Hist., ser. 5, vol. 16, pp. $407-421$. 
Henderson, J. R. 1888. Report on the Anomura collected by H. M. S. Challenger during the years 1873-76. Rep. Sci. Res. Voyage H. M. S. Challenger, Zool., vol. 27 , pp. i-xi, 1-221 pls. 1-21.

Laurie, R. D. 1926. Anomura collected by Mr. J. Stanley Gardiner in the Western Indian Ocean in H. M. S. "Sealark." Trans. Linn. Soc. London, ser. 2, Zool., vol. 19 , pt. 1 , pp. 121-167, pls. 8, 9.

de Man, J. G. 1888. Bericht über die von Herrn Dr. J. Brock im indischen Archipel gesammelten Decapoden und Stomatopoden. Arch. Naturg., vol. 53, pt. 1, pp. $215-600$, pls. $7-22 \mathrm{a}$.

de Man, J. G. 1902. Die von Herrn Professor Kükenthal im indischen Archipel gesammelten Decapoden and Stomatopoden. Abh. Senckenb. Naturf. Ges., Frankfurt a.m., vol. 25, pp. 467-929, pls. 19-27.

Melin, G. 1939. Paguriden und Galatheiden von Prof. Dr. Sixten Bocks Expedition nach den Bonin-Inseln 1914. Kungl. Svenska Vetensk.-Akad. Handl. ser. 3, vol. 18 , no. 2 , pp. 1-119, figs. $1-71$.

Miyake, S. 1953. On three new species of Galathea from the Western Pacific. J. Fac. Agr., Kyushu Univ., vol. 10, no. 2, pp. 119-208, figs. 1-6.

Miyake, S. and Baba, K. 1964. Two new species of Galathea from Japan and the East China Sea. J. Fac. Agr., Kyushu Univ., vol. 13, no. 1, pp. 205-211, figs. $1-4$.

Miyake, S. and Baba, K. 1965. Some galatheids obtained from the Bonin Islands. J. Fac. Agr., Kyushu Univ., vol. 13, no. 3, pp. 585-593, figs. 1-6.

Nobili, G. 1906. Faune carcinologique de la Mer Rouge. Décapodes et Stomatopodes. Ann. Sci. Nat. Zool., Paris, ser. 9, vol. 4, pp. 1-347, figs. 1-12, pls. 1-11.

Ortmann, A. E. 1892. Die Decapoden Krebse des Strassburger Museums. IV. Die Abtheilungen Galatheidea und Paguridea. Zool. Jahrb., Syst., Jena, vol. 6, pp. 241-326, pls. 11, 12.

Pocock, R. I. 1890. Report upon the Crustacea collected by P. W. Bassett-Smith, Esq., Surgeon R. N., during the survey of the Macclesfield and Tizard Banks, in the China Sea, by H. M. S. "Rambler," commander W. U. Moore. Ann. Mag. Nat. Hist., ser. 6, vol. 5, pp. 72-80.

Paul'son, O. 1961. Studies on Crustacea of the Red Sea with notes regarding other seas. Part 1. Podophthalmata and Edriophthalmata (Cumacea). pp. 1-164, pls. 1-21. The Israel Program for Scientific Translations, Jerusalem. "English translation of the original Russian publication for 1875."

Stimpson, W. 1858. Prodromus descriptionis animalium ....., Pars VII. Crustacea Anomura. Proc. Acad. Nat. Sci., Philadelphia, vol. 10, pp. 225-252.

Stimpson, W. 1907. Report on the Crustacea (Brachyura and Anomura) collected by the North Pacific Exploring Expedition, 1853-1856. Smiths. Misc. Coll., vol. 49 , pp. 1-240, pls. 1-26.

Yokoya, Y. 1933. On the distribution of decapod crustaceans inhabiting the continental shelf around Japan, chiefly based upon the materials collected by S.S. Soyo-maru, during the year 1923-1930. J. Coll. Agr., Tokyo Imp. Univ., vol. 12, no. 1 , pp. $1-226$, figs. $1-71$. 